This is an electronic reprint of the original article. This reprint may differ from the original in pagination and typographic detail.

Author(s): Sanakulov, Nodir; Karjaluoto, Heikki

Title: Consumer adoption of mobile technologies: a literature review

Year: $\quad 2015$

Version:

Please cite the original version:

Sanakulov, N., \& Karjaluoto, H. (2015). Consumer adoption of mobile technologies: a literature review. International Journal of Mobile Communications, 13(3), 244-275. https://doi.org/10.1504/IJMC.2015.069120

All material supplied via JYX is protected by copyright and other intellectual property rights, and duplication or sale of all or part of any of the repository collections is not permitted, except that material may be duplicated by you for your research use or educational purposes in electronic or print form. You must obtain permission for any other use. Electronic or print copies may not be offered, whether for sale or otherwise to anyone who is not an authorised user. 


\title{
Consumer Adoption of Mobile Technologies- A Literature Review
}

\author{
Nodir Sanakulov \\ PhD Candidate \\ sanakulov@gmail.com \\ Heikki Karjaluoto $^{1}$ \\ Professor of Marketing
}

Both at the Jyväskylä University School of Business and Economics, P.O.Box 35, FI-40014, University of Jyväskylä, Finland

\section{Biographical statements}

Researcher Nodir Sanakulov is a doctoral student at the University of Jyväskylä, Finland. His research deals with consumer acceptance of mobile technology from cultural perspective.

Heikki Karjaluoto is a Professor of Marketing at the University of Jyväskylä, Finland. He has also been Visiting Professor at the University of Hull since 2013. His research interests include electronic business in general and mobile business and commerce in particular. He has published over 60 articles in journals that include Electronic Markets, European Journal of Marketing, International Journal of Mobile Communications, Internet Research, Journal of Business \& Industrial Marketing, Telecommunications Policy, and Journal of Economic Psychology.

\footnotetext{
${ }^{1}$ Corresponding Author.Tel.: +358405767814

E-mail address: heikki.karjaluoto@jyu.fi
} 


\begin{abstract}
Although the total number of mobile subscriptions reached 6.8 billion worldwide (ITU, 2013) confirming in the process that mobile technology is widespread, academic literature has so far focused only on explaining adoption of mobile technology and services. This literature review analyses 67 studies from the period 2005-2013 and finds the following: a) most studies are quantitative in nature and come from Asia, b) the Technology Acceptance Model is the most used theory, and c) future research should also utilize qualitative methods and examine the behavioural outcomes of mobile adoption instead of simply adoption in consumer markets.
\end{abstract}

Keywords: consumer acceptance, mobile adoption, technology acceptance, literature review

\title{
1. Introduction
}

Today it is not hard to see that mobile technology has become a part of our lives (Liaw, Hatala and Huang, 2010) be it in the form of equipment or mobile services such as mobile banking (Lin, 2011; Kim, Shin and Lee, 2009), mobile learning (Keegan, 2002; Tan et al., 2012), mobile commerce (Roach, 2009), mobile-news (Chan-Olmsted, Rim and Zerba, 2013) and SMS marketing (Muk, 2007). Users of mobile phones now can access the internet, search for information, play games, watch videos, check stocks online and more. All these developments have resulted from technological advances (Okazaki and Mendez, 2012) enabling mobile phones to perform sophisticated tasks. In addition, handset manufacturers are lowering device costs while telecom companies are providing better voice and internet connections. Driven by such technological advancements and lower costs the number of mobile phone users is increasing. According to Gartner (2013) 1.75 billion units of mobile phones were sold to end-users in 2012 worldwide and the International Telecommunication Union reported that the total number of mobile subscriptions reached 6.8 billion (ITU, 2013).

The increasing number of mobile users has affected the size of the mobile market worldwide. IBM reported that mobile purchases soared with $24 \%$ of consumers using a mobile device to visit a retailer's web site, up from $14.3 \%$ in 2011 and mobile sales exceeded $16 \%$, up from $9.8 \%$ in 2011 (IBM, 2012). Gartner forecasts that the expenditure on mobile advertising will double every year to reach \$20.6 billion in 2015 from an estimated base of \$3.3 billion in 2011(Gartner, 2011). Currently, many players are jumping on the bandwagon hoping to establish their stakes in such a rapidly 
growing market. For example, popular video game makers such as Ubisoft and EA that have traditionally focused on Xbox, PSP, and PC platforms for their games are now developing games for mobile platforms. Internet giant Google is also offering most of its applications in mobile format. One of the brightest examples of this trend is the Finnish software company, Rovio, whose mobile game "Angry Birds" was the best-selling Apple application for many months (Financial Times, 2012).

However, to generate revenue from the mobile business, end-users must adopt the technology. Having a brand new piece of equipment to hand does not mean that the owner will use the available mobile services immediately (Verkasalo et al., 2010). On the other hand, equipment manufacturers are constantly developing newer handsets that are capable of handling technically demanding services such as live HD TV, stereo sound, fast steaming and more. Despite the above-mentioned advances, consumers use their mobile devices mainly for simple services such as voice calls and messaging (Nysveen, Pedersen and Thorbjørnsen, 2005). It seems that these technological advances are either loved or ignored by consumers.

The above-mentioned issue was observed at the level of the organization as well. An organization's main reason for incorporating technological advances is to reduce the amount of time required to complete a job (Aiello and Kolb, 1995). Obviously, the wise thing to do is to act fast and acquire the technology because it will enhance efficiency and productivity. However, when individuals are reluctant to act, making them accept something is never easy. Venkatesh et al. (2003) found that 50\% of organizations reported employee resistance when new technology was introduced. Users may or may not adopt a technology for a range of intrinsic and extrinsic reasons. For example, m-banking (Zhou, Lu and Wang, 2010a), m-TV (Choi and Totten, 2012), m-marketing (Persaud and Azhar, 2012), and m-learning (Park, 2011) are still in their infancy and adoption is advancing slowly.

The acceptance of technology has been a very important subject for the last 20 years or more. A considerable body of research has sought to understand the adoption process and the antecedents affecting it, and much of that research has made significant contributions to modern information systems (IS) research both theoretically and practically.

Our knowledge of what governs the acceptance of technology has been advanced by several seminal works. Fishbein and Ajzen (1975) proposed the Theory of Reasoned Action (TRA). Ajzen (1991) 
proposed the Theory of Planned Behavior (TPB). Davis (1989) proposed the Technology Acceptance Model (TAM). Liang and Wei (2004) proposed the Fit-viability Model (FVM). The Unified Theory of Acceptance and Use of Technology (UTAUT) was proposed by Venkatesh et al. (2003). Rogers (1995) proposed the concept of Diffusion of Innovation (DOI).

In the study of mobile technology adoption, researchers have been extending and utilizing existing theories and models to understand acceptance according to the technology and services they were focused upon. For example, TAM has been widely used for studying acceptance of e-learning (Park, 2009), web-shopping (Pavlou, 2003), m-gaming (Liu and Li, 2011), and m-TV (Jung, Perez-Mira and Wiley-Patton, 2009); UTAUT (Unified Theory of Acceptance and Use of Technology) (Venkatesh et al., 2003) for studying acceptance of mobile data services (Lu, Yu and Liu, 2009), internet banking (Im, Hong and Kang, 2011), m-banking (Yu, 2012a), tablet PCs (Anderson, Schwager and Kerns R.L., 2006), Information and Communication Technologies (Thong et al., 2011), Location-Based Services (Zhou, 2012); and TPB has been used for studying acceptance of m-learning (Cheon et al., 2012) and more.

One of the important responsibilities of all researchers is to remain abreast of developments in their area of interest. The popularity of mobile technology drove a rapid growth in interest in mobile adoption among academicians and practitioners seeking to explain the adoption process. When we look at the figures of published academic studies by country and year we can track that increased interest. However, the rapid increase in research complicates matters for researchers seeking to follow the developments and stay current. In concentrated environments, literature reviews are very useful for such purposes, serving to skim the most important information from previous studies and provide concise findings. There have been few literature reviews published in the IS study area and even fewer on mobile adoption at the individual level. Therefore, we felt such a review summarizing the papers published on mobile adoption was merited. This paper reviews studies on consumer adoption of mobile technology and analyses the findings, the models they applied, and determines the significant constructs affecting adoption of mobile technologies. At the conclusion of the study, we will be able to report which model or theory is more often used as a predictor of a certain technology. An effective review creates a firm foundation for advancing knowledge (Webster and Watson, 2002). 
Therefore, we will recommend constructs, theories, and specific details that we consider will be valuable for future research on consumer adoption of mobile technologies.

\section{Method}

To organize the review, the literature review papers were analysed thoroughly and all the recommendations made in previous research were considered. Before starting the literature review, a detailed plan was prepared and included instructions for each step with methods to be followed, the search method for publications, and details of the data extraction.

\subsection{Strategy for publication search}

The most important step in any literature review is searching for publications that cover the researcher's interests. In this particular review we are interested in mobile adoption studies available online. The search strategy consisted of five steps:

(a) Selection of keywords

In order to find relevant literature on mobile adoption it is important to identify keywords that help identify the required publication more efficiently. Therefore, a structured literature search was conducted and the search words used most often in the context of mobile adoption in the technology acceptance domain were identified. In addition, we canvassed the opinions of experienced researchers in this field. It is worth mentioning our efforts to identify synonyms, to account for differences in spelling (British English vs. American English). The keywords resulting from the process are shown in Table 1. Both words "acceptance" and "adoption" were combined with "technology" and "mobile" to generate more results, although we were careful to restrict the results so as not to become overburdened with irrelevant material.

\begin{tabular}{|l|l|l|l|}
\hline \multicolumn{3}{|c|}{ Search words } \\
\hline mobile adoption & mobile acceptance & technology acceptance & technology adoption \\
\hline technology usage & mobile usage & adoption model & acceptance model \\
\hline
\end{tabular}

Table 1. Search words for articles relevant to mobile adoption and acceptance 
A further restriction placed on the search results related to year of publication, which was largely limited to 2010-2013, the restriction ensured the results were topical and also preserved our limited resources.

(b) Identification of internet resources available for search

All major resources such as Science Direct (Elsevier), Academic Search Elite (EBSCO), Electronic Journals Service (EBSCO), SCOPUS (Elsevier), Web of Science, ebrary, SpringerLink, Primo Central Index, and ProQuest Central (ProQuest) were used in the search for relevant articles. The literature review intends to include only those studies published in journals that are popular platforms for mobile technology studies. These journals are acknowledged publishers of distinguished work by people eminent in their field. The list of journals is provided in Appendix B.

(c) Additional search criteria

In addition to the articles yielded by the search, we analysed the articles that were recommended as further reading or cited in the research papers discovered. As a result, the final set of selected articles includes some published before 2010 .

(d) Criteria for inclusion

Having been identified by the search engine, each item's full description was screened to assist further selection. There were around 210 items chosen at that stage, and they were then subjected to selection criteria to ensure the study:

- was fully reported

- was an empirical study

- was a study of relevant mobile adoption

- included measures for independent and dependent variables

- had a sample size of at least 100 for analysis

- provided detailed results of data analysis

In addition, as mentioned earlier, in this literature review we focused on mobile adoption at the consumer level only. Ultimately, 67 publications were included in the final review (Appendix A).

There were some articles excluded from the final list during individual analysis of them, on the grounds that the same data had been used for more than one study report. There are cases where one study involved conducting a survey in two countries and comparing the results to determine the 
differences. For the purposes of this review, such cases were considered as two separate studies because the data were analysed separately.

\subsection{Strategy for data extraction}

Once the publications were chosen, each was studied thoroughly and researchers took notes on important points and then completed a data extraction form. Apart from basic information on the study, the data extraction form included sections such as models used, proposed paths between variables, accepted paths, technologies studied, if technology use was voluntarily or not, if users had prior experience or not, original sample sizes, sample sizes used for analysis, response rates, whether the sample population was homogeneous or heterogeneous, survey mode (online/offline), and location of the study. The data extraction file also included any special notes the researchers made to facilitate future research. Each data extraction file was rechecked against the others to compare each section to identify any similarities, and those that shared the same data were excluded.

\subsection{Data extraction}

Each study included in the final review list was read and the required data extracted by filling out a data form. During this process important points and unique information mentioned in the articles were separately recorded for possible future reference. Since only one person was responsible for this process, on occasion, data checking was performed by a colleague of the authors. The check involved randomly picking a study to read and extracting data from it. The data were then compared by two different people to ensure the data were substantially the same as in the original record. Once reading and data extraction were complete, the resulting dataset was reviewed by academic supervisor, who offered practical suggestions to improve the usability of data extracted.

\section{Results}

Webster and Watson (2002) have suggested a concept-centric approach to researchers structuring a review, and that approach has been adopted here. All the articles included in final list were categorized according to the model and theory used to study mobile adoption.

The majority of studies (48 of 67 or $72 \%$ ) included in this review were published between 2010 and 2013, and the remainder were included because they were cited in the papers of that majority group.

Figure 1 illustrates the detailed publishing timeline of the studies included. 


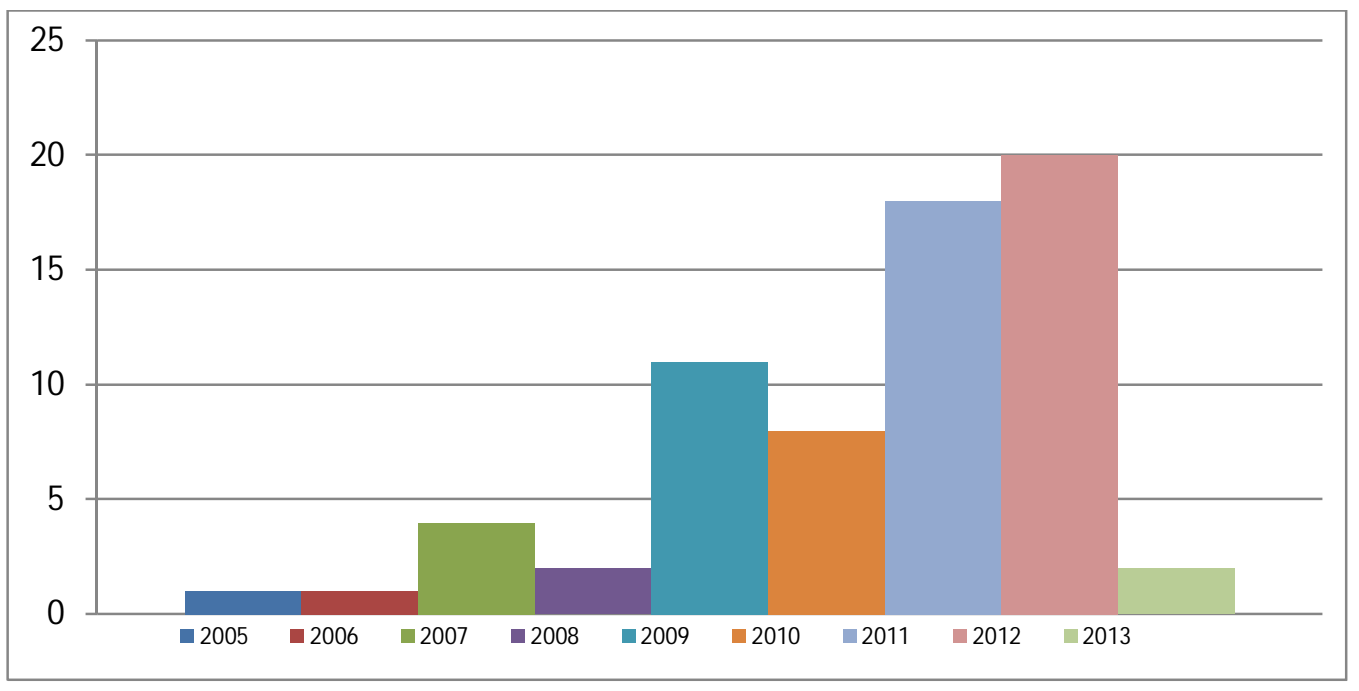

Figure 1. Allocation of reviewed studies according to year of publication

Each of the studies reviewed used a survey instrument to collect empirical data. It is also worth mentioning that a significant number of studies (25 of the 67) used online data collection methods, while 32 studies conducted solely a face-to-face survey. In only five cases were both online and faceto-face methods used, while five studies neglected to detail which approach had been used.

Overall, studies were conducted in 18 different countries throughout Asia, the Middle East, Europe, and North America. When categorized by location, China tops the list with 14 studies (21\%), followed by Taiwan with $11(16 \%)$, and they are followed by the USA with $10(15 \%)$. The allocation of studies by geographic distribution is shown in Table 2 . There were also studies that conducted surveys in two different countries to compare the acceptance factors. However, as mentioned in the section on the method of data extraction, we counted those as two different studies, because the survey results were not dependent on each other.

A simple statistical analysis of the IS adoption models and theories used in the studies confirmed TAM to be the most frequently used (in 47 of 67 studies) followed by UTAUT in 15 studies. Other theories/models such as TPB, Brehm's Reactance Theory, Task Technology Fit (TTF), and IDT (Innovation Diffusion Theory) also contributed.

It is important to note that while a few studies were wholly based on one theory, in many cases these models were integrated with other models or incorporated specific constructs of other theories and models to extend TAM and UTAUT. One study broke with the convention of using established 
theories and models, deploying Microsoft Usability Guideline (MUG) dimensions to explain the factors that determine a consumer's intention to make mobile payments (Liu, Wang and Wang, 2011).

\begin{tabular}{|l|r|r|l|r|r|}
\hline Country & \multicolumn{2}{|l|}{$\begin{array}{l}\text { Studies } \\
\text { conducted }\end{array}$} & $\%$ & Country & \multicolumn{2}{l|}{$\begin{array}{l}\text { Studies } \\
\text { conducted }\end{array}$} \\
\hline Canada & 1 & $1 \%$ & Netherlands & 1 & $1 \%$ \\
\hline China & 14 & $21 \%$ & Nigeria & 1 & $1 \%$ \\
\hline Finland & 1 & $1 \%$ & Pakistan & 1 & $1 \%$ \\
\hline Germany & 1 & $1 \%$ & Singapore & 1 & $1 \%$ \\
\hline Greece & 2 & $3 \%$ & Taiwan & 11 & $16 \%$ \\
\hline Hong Kong & 2 & $3 \%$ & Turkey & 1 & $1 \%$ \\
\hline India & 1 & $1 \%$ & UAE & 1 & $1 \%$ \\
\hline Korea & 9 & $13 \%$ & USA & 10 & $15 \%$ \\
\hline Kuwait & 1 & $1 \%$ & & & \\
\hline Malaysia & 8 & $12 \%$ & Total & 67 & \\
\hline
\end{tabular}

Table 2. Studies allocated according to geographic distribution

There are a few conceptual models proposed in mobile adoption studies that we reviewed (Kim, Chan and Gupta, 2007; Cheon et al., 2012), and a full list of models and theories supporting the studies reviewed is presented in Table 3.

Theories and models

\begin{tabular}{|l|l|}
\hline Technology Acceptance Model (TAM) & Davis, 1989 \\
Technology Acceptance Model 2: (TAM2) & Venkatesh and Davis, 2000 \\
$\begin{array}{l}\text { Unified Theory of Acceptance and Use of Technology } \\
\text { (UTAUT) }\end{array}$ & Venkatesh et al. 2003 \\
$\begin{array}{l}\text { Unified Theory of Acceptance and Use of Technology 2 } \\
\text { (UTAUT2) }\end{array}$ & Venkatesh et al. 2012 \\
Theory of Planned Behavior (TPB) & Ajzen, 1991 \\
Task Technology Fit (TTF) & Goodhue and Thompson, 1995 \\
$\begin{array}{l}\text { Customer Experience Management (CEM) } \\
\text { Triandis' Model }\end{array}$ & Schmitt, 1999 \\
\hline Model of Innovation Resistance (MIR) & Triandis, 1977 \\
Innovation Diffusion Theory (IDT) & Ram, 1987 \\
\hline Theory of Reasonable Action (TRA) & Rogers, 1995 \\
\hline
\end{tabular}

Table 3. Models and theories used in the reviewed studies

When we analysed the data extracted according to the theories, models and frameworks used, the studies were categorized as follows: 
a) Those that extended TAM and/or UTAUT either with existing theories and models, or by including constructs from existing theories, or by including additional constructs and moderators. This category comprises 40 studies.

b) Those that integrated TAM either with other established theories and models or by including constructs from existing theories, or by including constructs relevant to the technology studied. This category comprises 12 studies.

c) Those that based their research design on original theories and models. In this category only TAM and UTAUT were used. Only four studies were included in this category.

d) Those that developed new conceptual frameworks and models based either on existing theories or by including specific constructs related to the technology studied and constructs from established theories and models, or by developing brand new constructs. There were 11 such studies.

The TAM has been most frequently used in studies to examine mobile adoption behaviour, which includes m-banking (Amin et al., 2008; Kalaiarasi and Srividya, 2013; Teo et al., 2012), m-learning (Shin, 2011), m-commerce (Zhang, 2009; Bhatti, 2007), m-data services (Karaiskos et al., 2012), smartphones (Teng and Lu, 2010), and m-financial services (Lee et al., 2012).

\subsection{Technology Acceptance Model}
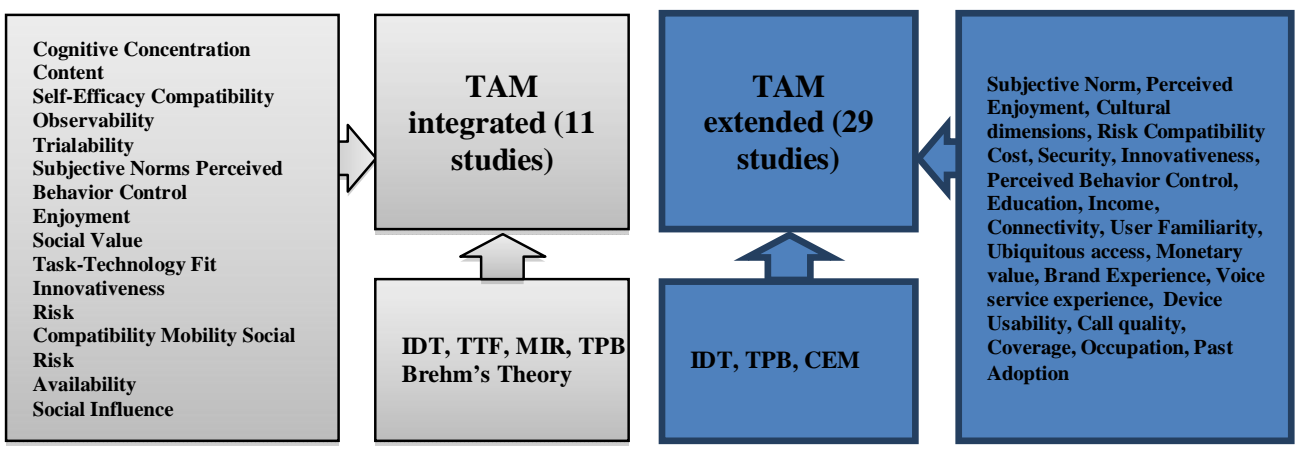

Figure 2. Theories and constructs used in integrating and extending TAM

TAM was proposed by Davis (1989) as an appropriate mechanism for predicting adoption of new technology within a group and organization. It is based on TRA (Fishbein and Ajzen, 1975) and it hypothesizes that technology adoption is based on the user's attitude and intentions. Perceived 
usefulness (PU), perceived ease of use (PEOU), attitude towards use, and behavioural intention (BI) were proposed as internal variables affecting technology usage.

Our sample includes some studies that extended the existing TAM by including additional constructs (Figure 2). TAM was also integrated with other theories and models such as IDT (Mallat et al., 2009), TPB (Tsai, 2010), TTF (Shih and Chen, 2013; Zhou, Lu and Wang, 2010b), and Brehm's theory (Lee, Chung and Kim, 2013). There are a few studies that have included TAM constructs in their conceptual models (El-Gayar, Moran and Hawkes, 2011).

\subsection{Unified Theory of Acceptance and Use of Technology}

The Unified Theory of Acceptance and Use of Technology is the second most used approach in mobile adoption studies such as those on mobile data services (Lu, Yu and Liu, 2009), mobile wallets (Shin, 2009), mobile online gaming (Chen and Kuan, 2012), and mobile banking (Tan et al., 2010; Zhou, Lu and Wang, 2010b).

The major advantage of UTAUT is that it includes the integration of the constructs of eight theoretical models of user behaviour: TAM, TRA, the motivational model, TPB, a model combining the TAM and TPB, the model of PC utilization, IDT, and the social cognitive theory (Venkatesh et al., 2003). It consists of four direct determinants of usage intention and behaviour: performance expectancy (PE), effort expectancy (EE), social influence (SI) and facilitating conditions (FC). There are also four moderators: gender, age, experience, and voluntariness of usage posited to mediate the impact of the four key constructs on usage intention and behaviour. UTAUT tries to explain a user's intention to use an information system and user behaviour (Venkatesh et al., 2003).
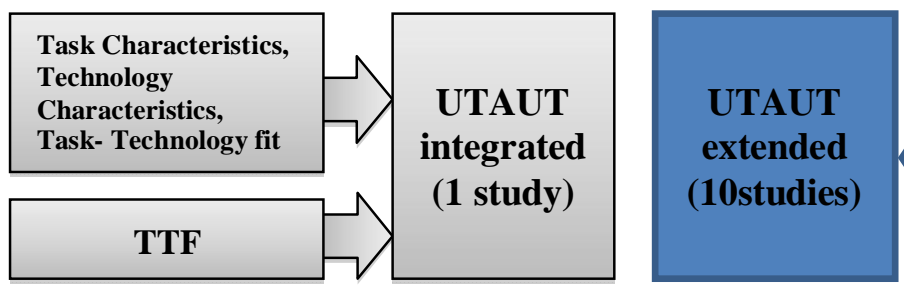

Price value, Hedonic motivation, Habit, Perceived Security, Trust, Self Efficacy, Perceived Usefulness, Perceived Ease of Use, Perceived Credibility, Perceived Financial Cost, Privacy Concern,

Perceived Playfulness, Perceived Value, Anxiety, Convenience, Device Efficacy

Figure 3. Theories and constructs used in integrating and extending UTAUT

Like TAM, UTAUT was extended with new additional constructs or moderators and integrated with other existing theories (Zhou, Lu and Wang, 2010b; Wang and Wang, 2010) or original variables 
were replaced (Tan et al., 2010) (Figure 3). In addition, UTAUT constructs were used in one conceptual model.

\subsection{The Triandis Model}

In addition to the frequently used models and theories, the Triandis model (Karaiskos et al., 2012) was studied individually. Karaiskos et al. used the Triandis Model by incorporating PU, PEOU, Perceived Enjoyment (Van der Heijden, 2003) and Perceived Value to study predictions of the adoption of mobile data services.

\subsection{Conceptual frameworks}

The database has records of 11 studies that proposed conceptual frameworks to study adoption of mobile learning (Iqbal and Qureshi, 2012), mobile commerce (Dai and Palvi, 2009), mobile-news (Okazaki and Mendez, 2012), 3G services (Chong et al., 2010), and tablet PCs (El-Gayar, Moran and Hawkes, 2011). Most of these studies included constructs from established theories and models while a few others utilized determinants such as utilitarian value, social value, interpersonal influence, trust, enjoyment, technicality, perceived fee.

\subsection{TRA, TPB, TTF, IDT, Brehm's reactance theory, CEM, MIR.}

Even though these theories and models were not studied individually, they were integrated with other models and theories, or their constructs were borrowed to explain mobile adoption and develop conceptual frameworks.

\subsection{The most significant variables affecting mobile adoption}

During the data extraction process, the information on proposed paths between independent and dependent variables leading to adoption of mobile technologies and services was included. In addition, paths between dependent and independent variables, and the determinants of independent variables were recorded. The statistically significant paths were indicated separately to estimate the prediction power of the analysed variables based on simple statistics. Since the current review includes all mobile adoption related studies, the number of proposed paths was considerable. Therefore, the authors decided to analyse only those used in more than two studies. For example, in a study of students' acceptance of tablet PCs, El-Gayar et al. (2011) analysed the many available paths including those between SI and PE, EE and PE, and these two last paths were acknowledged to be 
significant ones. However, apart from El-Gayar et al. there were no other researchers studying these same paths in our dataset. For this reason, the aforementioned paths were dropped from further analysis. The paths that were frequently tested and their acceptance rates are illustrated in Table 4.

\subsubsection{Determinants of Perceived Usefulness and its effects}

According to TAM, an individual's behavioural intention to use a technology depends on two determinants, PU and PEOU. PU is defined as the extent to which a person believes that using the technology will enhance his or her job performance (Davis, 1989). PU directly affects the intention to use, if users believe that using the technology will benefit them and serve whatever purpose they have set for using the technology. Furthermore, PU is considered to be affected by PEOU (Figure 3). Since the introduction of PU, it has been studied by researchers interested in its external variables and extended in various contexts (Rouibah, Abbas and Rouibah, 2011; Lin, 2011). However, PU has been criticized for being broad based (Moore and Benbasat, 1991) and for being treated as a black box, with study after study reiterating its importance, while little effort has been applied to investigating what actually makes a system useful (Benbasat and Barki, 2007).

In terms of study frequency, the relationship between PU and intention to use the technology was the most frequently studied path. In our dataset, 37 of $67(76 \%)$ studies investigated this relationship in various contexts, and in 28 of $37(76 \%)$ studies this relationship was reported to be statistically significant.

TAM proposes that PEOU indirectly affects BI by influencing PU. This is assumed because the ease of technology usage may also cause its users to accept its usefulness, and this connection has been established in some studies (Liao, Tsou and Huang, 2007). This relationship was the second most investigated one in our dataset. Of our 67 studies, 30 (45\%) investigated this path and $26(87 \%)$ of those reported it to be a significant one.

According to Davis (1989) PU has a positive effect on user attitudes. A user believing that using a technology will enhance job performance will form a positive attitude to that technology. This relationship has been proven in numerous studies. Moreover, among the works reviewed are $21(31 \%)$ that investigated this path: all of them (100\%) reported this relationship to be significant. 
There are some cases that tried to determine the external variables of PU. Bhatti (2007) incorporated a path in which subjective norms (SN) affect PU positively; Lu et al. (2005) studied the effect of SI in the form of SN and image on PU; Lopez-Nicolas et al.(2008) tested the effect of SI on PU. These relationships were reported to be significant in all three studies.

\subsubsection{Determinants of Perceived Ease of Use and its effects}

PEOU is defined as the degree to which a person believes that using the system is free of effort (Davis, 1989). It is considered to be the main determinant of the intention to use a technology. The relationship between PEOU and many other variables was tested in numerous previous IS studies in various contexts. In terms of the effects of PEOU on other variables, some of the studies that were analysed tested three different relationships: PEOU-PU (reported above), PEOU-BI, and PEOUAttitude. In 28 studies (42\%) the relationship between PEOU and BI was tested and in 20 of those 28 cases $(71 \%)$ this path was deemed significant. The relationship between PEOU and Attitude was tested in 21 studies (31\%) and 17 of them (81\%) reported the path to be significant, leaving only four studies deeming it insignificant.

The three studies mentioned above that focused on determining the external variables of PU did the

same for PEOU. Moreover, the results obtained were identical and indicated SN and SI have a positive impact on PEOU.

\subsubsection{Attitude and Behavioural Intention}

According to TRA (Fishbein and Ajzen, 1975) BI is affected by an individual's attitude and SN. Consequently, attitude towards IS determines the BI. This path between attitude and BI was included in the TAM by Davis (1989) and has been tested many times. Our dataset of 67 cases includes 27 such cases (40\%) and only one study found it insignificant; the significance rate is therefore $96 \%$.

\subsubsection{Social factors}

The social factor is not incorporated in TAM, while in UTAUT it has been recognized as one of four main determinants of BI. SI is the extent to which a person perceives that important others believe he or she should use a new information system (Venkatesh et al., 2003). Prior research has confirmed its importance as a determinant of BI (Venkatesh and Davis, 2000; Wu, Tao and YangJ, 2007). In the literature reviewed, 15 studies (22\%) tested the effects of SI on BI and in 13 of those $15(87 \%)$ its 
influence was confirmed to be significant. Interestingly, while all UTAUT based studies positively confirmed this path, it was rejected in an extended TAM ( $\mathrm{Lu}$, Yao and Yu, 2005) and in a conceptual framework (Iqbal and Qureshi, 2012).

In addition, four studies (6\%) tested the effects of social factors on users' attitude and in all cases this path was confirmed to be significant.

\subsubsection{Performance expectance, effort expectancy and facilitating conditions}

According to the UTAUT, PE, EE, and FC are the main determinants of BI. These constructs are frequently used to extend other models and theories in various contexts. The papers analysed include examples that tested these constructs as independent variables positively affecting relationships with attitude and BI.

PE is similar to the PU of TAM and the relative advantage of IDT and it refers to the degree to which an individual believes that using the system will enhance his or her job performance (Venkatesh et al., 2003). The effect of PE on BI was tested in nine studies (13\%) and all of them confirmed it as the main determinant of BI. Furthermore, four studies $(6 \%)$ tested the PE effect on attitude, and found it significant.

EE is similar to the PEOU of TAM and the complexity of IDT and is the degree of ease associated with technology usage (Venkatesh et al., 2003). In our dataset, eight studies (12\%) tested the relationship between EE and BI. In five cases from the total of sixty-seven (7\%) this positive path was statistically proven. Similarly, the path between EE and attitude was tested and confirmed in four of the total publications reviewed (6\%).

FC is similar to perceived behavioural control of TPB and reflects the effect of a user's knowledge, ability, and resources. It is defined as the degree to which a person believes that the organizational and technical infrastructure exists to support system usage (Venkatesh et al., 2003). According to UTAUT, BI and FC determine technology use. In UTAUT2, Venkatesh et al. (2012) proposed that FC has a direct effect on BI moderated by age, gender, and experience. However, this path was tested prior to the proposed UTAUT2 in various contexts and seven such studies (10\%) were included in our dataset. Only in one study was this path rejected. The effect of FC on attitude was tested in three studies (4\%) and confirmed in only two. 


\begin{tabular}{|l|r|r|r|}
\hline \multicolumn{1}{|c|}{ Tested paths } & \multicolumn{1}{c|}{$\begin{array}{c}\text { Proposed } \\
\text { cases }\end{array}$} & \multicolumn{1}{c|}{$\begin{array}{c}\text { Accepted } \\
\text { cases }\end{array}$} & $\begin{array}{c}\text { Acceptance } \\
\text { rate }\end{array}$ \\
\hline PU->BI & 37 & 28 & $76 \%$ \\
\hline PEOU->BI & 28 & 20 & $71 \%$ \\
\hline A->BI & 27 & 26 & $96 \%$ \\
\hline PE->BI & 9 & 9 & $100 \%$ \\
\hline EE->BI & 8 & 5 & $63 \%$ \\
\hline SI->BI & 15 & 13 & $87 \%$ \\
\hline FC->BI & 7 & 6 & $86 \%$ \\
\hline PEOU->Attitude & 21 & 17 & $81 \%$ \\
\hline PU->Attitude & 21 & 21 & $100 \%$ \\
\hline PE->Attitude & 4 & 4 & $100 \%$ \\
\hline EE->Attitude & 4 & 4 & $100 \%$ \\
\hline SI->Attitude & 4 & 4 & $100 \%$ \\
\hline FC->Attitude & 3 & 2 & $67 \%$ \\
\hline PEOU->PU & 30 & 26 & $87 \%$ \\
\hline SI->PU & 3 & 3 & $100 \%$ \\
\hline SI->PEOU & 3 & 3 & $100 \%$ \\
\hline
\end{tabular}

Table 4. Frequently tested paths with acceptance rates

\subsection{Top three areas studied in mobile adoption}

The literature on mobile adoption reviewed included many topics such as mobile data services, mobile banking, mobile learning, mobile devices, mobile commerce, mobile gaming, mobile financial services, mobile wallets, mobile ticketing, mobile marketing, location-based services, and more. The top three areas studied are mobile data services (9 studies), mobile banking (7 studies), and mobile learning (7 studies).

\subsubsection{Mobile data services}

In the nine studies attempting to explain adoption of mobile data services, the authors mostly extended existing theories (TAM and UTAUT) by focusing on mobile data service-specific determinants such as PE, perceived value, SI, perceived enjoyment, voice service experience, flow experience, perceived availability, the variety of services, and perceived advantage that had a significant effect on adoption. In the majority of the studies PU is the strongest influencer of adoption (see Table 5). Along with the original variables, social factors (Karaiskos et al., 2012), enjoyment (Kim, Chan and Gupta, 2007) and perceived value (Wang and Wang, 2010) were shown to be important variables. Those studies that determined the strength of the attitude to using a system (Suki, 2011; Kuo and Yen, 2009) have confirmed it to be the best predictor of use. 


\subsubsection{Mobile banking}

Results derived from the mobile banking papers were not very different than those from the mobile data services studies, which included PU and PEOU. As in other areas, TAM was the most often used theory and combined analysis showed that PEOU was the most important factor affecting both intention and perceived usefulness (Table 5).

In studying mobile banking adoption, the main focus was on the risk, financial costs, credibility, security, usefulness, and ease of use of using mobile banking. The study findings show the strong significance of the above-mentioned factors in the adoption of mobile banking. In this group of mobile adoption studies, TAM, UTAUT, and TTF were employed alongside additional constructs to explain adoption.

\subsubsection{Mobile learning}

Analysing the dataset extracted from mobile learning adoption literature showed that the main determinants of mobile learning adoption were PU, PEOU, SN, and FC (Table 5). Quality, past experience, and system accessibility were also statistically proven to be significant determinants of adoption. Studies on mobile learning also bore similarities to previous areas in terms of theories used and variable classification according to their strengths. The integrated variables that proved to be significant factors included cultural aspects, service quality (Chong et al., 2011), and subjective norms (Tan et al., 2012). Furthermore, according to Cheon et al. (2012), perceived behavioural control is a key factor in explaining intention to use mobile learning, and outweighs the effects of attitude and social norms.

In all areas, PU is the most influential factor on attitude, followed by PE, PEOU, and EE (Table 5). The effect of PU on attitude was strongest in mobile data services studies (on average 0.535). On average, attitude was the strongest predictor of intention to use, followed by the effect of PU and SI/subjective norms. The effect of attitude on intention was extremely strong in mobile data services studies (0.818). FC was found to be a stronger predictor of use than intention.

\section{Discussion}

This study presents a systematic literature review of mobile adoption studies. In conducting the current review, the authors followed the recommendations made by Webster and Watson (2002). The 
current review covers studies addressing mobile adoption published between 2005 and 2013. The studies selected were 66 journal articles and one conference paper. Of the total of 67,48 were published between 2010 and 2013. The rise in interest in this area is particularly evident since 2011.

\begin{tabular}{|l|c|c|c|}
\hline Variables & Attitude & Intention & Use \\
\hline Attitude & - & $0.599\left(0.818^{1}\right)\left(0.391^{3}\right)$ & - \\
\hline Intention & - & - & 0.307 \\
\hline PU & $0.450\left(0.535^{1}\right)\left(0.474^{3}\right)$ & $0.318\left(0.409^{1}\right)\left(0.281^{2}\right)\left(0.248^{3}\right)$ & - \\
\hline PEOU & $0.300\left(0.362^{3}\right)$ & $0.201\left(0.240^{1}\right)\left(0.241^{2}\right)\left(0.156^{3}\right)$ & - \\
\hline PE & 0.306 & 0.231 & - \\
\hline EE & 0.299 & 0.164 & - \\
\hline SI / Subjective norms & 0.275 & $0.298\left(0.330^{1}\right)\left(0.422^{3}\right)$ & - \\
\hline FC & 0.288 & $0.238\left(0.205^{3}\right)$ & $0.527\left(0.400^{2}\right)$ \\
\hline Value & - & $0.196\left(0.258^{1}\right)$ & - \\
\hline Enjoyment & - & $0.220\left(0.237^{1}\right)$ & - \\
\hline Perceived financial cost & -0.062 & $-0.192\left(-0.103^{1}\right)$ & - \\
\hline Perceived self-efficacy / PBC & - & 0.135 & - \\
\hline
\end{tabular}

Table 5. Meta- analysis of the average (mean) path coefficients of mostly tested paths in all reviewed studies

Notes: 1 Mobile data services studies, 2 Mobile banking studies, 3 Mobile learning studies

\subsection{Implications for theory and practice}

The results of this literature review indicate that in most studies the research models were based on either TAM or UTAUT. Apart from constructs specific to the area under study included in the models, most constructs were borrowed from established theories and models, the list of which can be found in Figures 2 and 3. Some studies developed conceptual models (Kim, Chan and Gupta, 2007) and frameworks incorporating constructs and paths from existing theories.

The paths between various variables used in the models and their significance were also analysed separately. The frequency of paths was proportional to the models and theories used in the reviewed studies. Therefore the most tested paths were between TAM constructs. For example, the effect of PU on BI was tested in 37 studies and accepted in 28 , an acceptance rate of $76 \%$. Interestingly, social factors were highly influential on both BI and Attitude in all countries, with the lowest acceptance rate being $87 \%$. In addition, the acceptance rates of the paths proposed between UTAUT constructs and attitude and BI were high. Analysing the significance of various paths gave us a good opportunity to compare the strengths of the assorted variables. 
Common practical implications suggested by the studies on mobile data services mainly included factors relevant to the area, such as quality, security, and trust. For example, for Chinese users' intention to use was greatly influenced by voice service quality (Qi et al., 2009). In addition, factors shown to strengthen well-established variables like PEOU, PU, social influence, perceived advantage should be considered seriously as they play significant roles in forming intention. Scholars stress the importance of fun, enjoyment of data services, along with user-friendly applications with straightforward interfaces. Delivering those attributes would require all parties involved in data services, such as gadget makers, programmers, service providers, to work together. Uncertainty in accessibility and slow data transaction will lead to a perception of unreliable services.

In terms of the adoption of mobile banking, Yu (2012b) suggests that all managerial activities should target social influence, credibility, perceived financial cost, and performance expectancy. The majority of the studies reviewed suggest managers, service providers, and banks develop user-friendly and easy to use software, websites, and services. In addition, increasing customers' awareness of mobile banking services, the usefulness of mobile banking and enhancing customer confidence about mobile banking were also suggested. For this purpose, banks should take advantage of employees, customer service, and manuals in order to encourage trials, to boost confidence and to convey the value of mobile banking. The unique implementation included in Yu's work (2012b) that suggested enhancing compatibility between services and lifestyles of users like students and businessmen and the perceived financial cost should be carefully considered, especially, as the research results suggest, for subjects younger than 30 and those over 50. Some research results showed that social factors play an important role in forming intention to use mobile banking. Therefore, we would suggest managers to consider this factor.

The practical implications of mobile learning studies focus on service and technical factors, and social factors along with PEOU, PU, and PE, which were classified as robust factors forming intention. Moreover, some of the factors stressed, were mobile learning specific. For example, learning content should be at least equally well prepared as materials obtained during face-to-face interaction; awareness among potential users should be enhanced; and universities should provide high-speed WiFi zones and inexpensive devices. Special attention should be paid to the role of social factors in 
forming awareness and positive attitude, suggesting mobile learning should be promoted in social networks. Cheon et al. (2012) argue that perceived behavioural control is the key factor affecting adoption and recommend enhancing it and trying to improve students' attitudes by providing opportunities to learn the various functions of devices enabling mobile learning.

When we compare the implications mentioned in the above areas, we see that regardless of the area of study, ease of use, the user friendliness of an interface/software/website, the service quality, PU, and social factors played important role in forming intention to use. Moreover, the majority of studies suggested that all players involved in these services should work together in order to satisfy user needs and requirements because they are interdependent on devices, service providers, and telecommunication operators.

\subsection{Future research directions}

Against this backdrop, the following future research directions in the realm of mobile adoption can be identified. Our recommendations are based on the suggestions made by the authors of the studies we reviewed and some are based on our own observations on the 67 works.

\subsubsection{Constructs}

In terms of constructs, future studies should incorporate more technology-specific and service-specific constructs. For example, for mobile banking adoption some researchers have suggested a focus on cost and a trust or price/cost variable for mobile VOIP (voice over internet protocol) adoption. We believe that as technological developments advance there will be a need to address adoption with new constructs. These recommendations were echoed in the works we reviewed.

\subsubsection{Relationships between variables}

Another issue we noticed in the studies was that very few researchers were interested in studying the determinants of major independent variables such as PEOU and PU, both of which are considered important factors in technology acceptance. In most cases, models were created on the basis of widely accepted paths such as the relationship between PEOU and Intention, PU and Intention, PE and BI, EE and BI. There is already a sufficient body of work confirming these relationships while more research focus would be merited on other determinants and the relationships between them. For example, no significant contribution to understanding the connections between habit and actual use or 
intention and actual use was recorded. Finally, adoption studies should start to emphasize the outcomes of adoption. The mobile sector includes very few studies looking at how the use of mobile technology affects behavioural outcomes of customer relationships such as customer loyalty, satisfaction, share-of-wallet or positive word-of-mouth.

\subsubsection{Cultural factors}

We also noticed that quite a number of studies examined the effects of cultural factors on mobile adoption. Those that did so illustrated the importance of cultural factors by presenting statistical evidence (Choi and Totten, 2012). It follows that in order to understand adoption across cultures, more cross-cultural studies should be conducted.

\subsubsection{Longitudinal research}

We live in an era of technological advances that are shaping our lifestyles and behaviours. With these advances, exposure to new technologies and usage habits change and it is inevitable that individual perceptions change over time. Therefore, longitudinal research should be conducted to reveal the changes in how people perceive technology.

\subsubsection{Qualitative research}

The search for material that informs the current paper rarely unearthed studies based on qualitative methodology. Qualitative research on user behaviour would improve the quality of predictions relating to adoption. The review strongly indicates that research quality improves significantly when both qualitative and quantitative approaches are available.

\subsubsection{Heterogeneous, larger sample}

When we analysed the dataset, 31 out of 67 studies used a homogenous sample, mainly comprising university students and faculty members, to support their analysis. A homogenous sample presents a major barrier to findings being generalizable. Furthermore, sample size was something of a concern among the studies reviewed, as many did not exceed 200 respondents and very few exceeded 500 . The sample size determines the significance of findings and having large sample improves the credibility and supports the generalization of the results. Therefore, study samples should be heterogeneous in nature and large in number; a recommendation echoed in many studies. 


\subsubsection{Older users}

The area of study being mobile adoption caused the researchers to focus on young users who are considered to be more interested in fashionable technology, and in many studies, older users were ignored despite this group forming a significant proportion of any country's population. Sample distribution should be representative of the actual demographic in order to support the generalization of findings.

\subsubsection{Experienced users}

In technology and service adoption studies, the survey respondents should include individuals with experience of using the technology in question. Tsai (2010) illustrated the importance of following this method when studying the usage intentions relating to mobile travel guide systems, by distributing such systems to the respondents to use for a period before capturing their experiences through a questionnaire.

\subsubsection{Mature communities}

Another concern encountered in the studies relating to certain technologies and services was the maturity of communities. The frequency of services studied in each country is also to some extent an indicator of maturity. For example, mobile ticketing has been widely used in some European counties and the current review included a mobile ticketing acceptance study conducted in Finland (Mallat et al., 2009). However, we could not find any similar study conducted in other counties. On the other hand, conducting a study in a country with an immature user community casts doubt on how generalizable the results obtained are. Zhou et al. (2010b) argue mobile banking in China is still in its infancy, suggesting the results they obtained cannot be generalized to other countries.

\subsubsection{Wider geographies}

The recommendation most frequently made in the reviewed studies was to conduct similar research in other countries in order to generalize the findings. Until that is done, it is not wise to depend on the results obtained in other countries, where acceptance may be affected by many elements including cultural, economic, and technical factors. 


\subsubsection{Focus on software}

A mobile device is of no use without the operating system and software to run it. The recent reports of investments in the software industry show the importance of that aspect. For example, Google Maps and Gmail mobile applications are becoming part of mobile technology. Another example is mobile VOIP enabling a user to make good quality international phone calls at cheaper rates than are offered by telephone companies and sometimes to make free calls. Cost is a major main driver of the popularity of VOIP. Our sample contains a study by Shin (2012), which researches VOIP use over mobile phones in South Korea. On the other hand, it has now become normal to hear arguments over the comparative merits of operating systems for mobile phones and potential customers may base their purchase decision on that aspect. Accordingly, studies examining the adoption of software and operating systems would be welcome.

\subsection{Limitations}

The current research inevitably has some limitations. The first arises from the failure of an initial plan to measure relations between dependent and independent variables of the reviewed studies and to provide prediction strengths for each one. However, in most studies the data analysis part only included tests of those paths that the authors had investigated, making it impossible to conduct the further analysis required to achieve the planned purpose. In future literature reviews, authors should consider this issue during their screening process if they wish to perform an extended meta analysis. Second, we covered the studies that focus on mobile adoption by customers and not in groups and organizations. The review results indicate that the most frequently used model was the TAM, and we know that TAM was developed to predict the acceptance of new technology within groups or in organizational settings (Davis, 1989). Owing to the limited number of studies of mobile acceptance in organizations, we decided not to include that topic. However, future studies should include research that focuses on acceptance in both settings to offer results of a wider scope.

Third, this review focuses on mobile adoption only and does not extend to reviewing works on postadoption, re-use or continuance of mobile technologies. Future literature reviews should also incorporate such publications. 
Finally, a shortage of resources dictated that the literature review could essentially cover only material published since 2010. The final review does include some studies conducted before 2010 that were chosen either because they were repeatedly cited by authors or were suggested to be relevant by colleagues. Many mobile adoption studies were conducted and published prior to 2010 that contributed to shaping this research area, and in fact, the introduction of mobile technologies predates the 1990s, and it must be considered a limitation of the current study that it was unable to include such earlier studies within its purview. 


\section{References}

Aiello, J.R. and Kolb, K.J. 1995, "Electronic Performance monitoring and social context: Impact on productivity and stress", Journal of Applied Psychology, vol. 80, no. 3, pp. 339-353.

Ajzen, I. 1991, "The theory of planned behavior", Organizational behavior and human decision processes, vol. 50, no. 2, pp. 179-211.

Amin, H., Hamid, M.A., Lada, S. and Anis, Z. 2008, "The adoption of mobile banking in Malaysia: The case of Bank Islam Malaysia Berhad (BIMB)", International Journal of Business and Society, vol. 9, no. 2, pp. 43-53.

Anderson, J.E., Schwager, P.H. and Kerns R.L. 2006, "The Drivers for Acceptance of Tablet PCs by Faculty in a College of Business", Journal of Information Systems Education, vol. 17, no. 4, pp. 429.

Benbasat, I. and Barki, H. 2007, "Quo vadis, TAM", Journal of the Association for Information Systems, vol. 8, no. 4, pp. 211-218.

Bhatti, T. 2007, "Exploring factors influencing the adoption of mobile commerce", Journal of Internet Banking and Commerce, vol. 12, no. 3, pp. 1-13.

Chan-Olmsted, S., Rim, H. and Zerba, A. 2013, "Mobile News Adoption among Young Adults Examining the Roles of Perceptions, News Consumption, and Media Usage", Journalism \& Mass Communication Quarterly, vol. 90, no. 1, pp. 126-147.

Chen, L.S. and Kuan, C.J. 2012, "Customer acceptance of playing online game on mobile phones", International Journal of Mobile Communications, vol. 10, no. 6, pp. 598-616.

Cheon, J., Lee, S., Crooks, S.M. and Song, J. 2012, "An investigation of mobile learning readiness in higher education based on the theory of planned behavior", Computers \& Education, vol. 59, no. 3, pp. 1054-1064.

Choi, Y.K. and Totten, J.W. 2012, "Self-construal's role in mobile TV acceptance: Extension of TAM across cultures", Journal of Business Research, vol. 65, no. 11, pp. 1525-1533.

Chong, A.Y., Darmawan, N., Ooi, K. and Lin, B. 2010, "Adoption of 3G services among Malaysian consumers: an empirical analysis", International Journal of Mobile Communications, vol. 8, no. 2, pp. 129-149.

Chong, J., Chong, A.Y., Ooi, K. and Lin, B. 2011, "An empirical analysis of the adoption of mlearning in Malaysia", International Journal of Mobile Communications, vol. 9, no. 1, pp. 1-18.

Dai, H. and Palvi, P.C. 2009, "Mobile commerce adoption in China and the United States: a crosscultural study", ACM SIGMIS Database, vol. 40, no. 4, pp. 43-61.

Davis, F.D. 1989, "Perceived usefulness, perceived ease of use, and user acceptance of information technology", MIS quarterly, , pp. 319-340.

El-Gayar, O.F., Moran, M. and Hawkes, M. 2011, "Students' Acceptance of Tablet PCs and Implications for Educational Institutions.", Educational Technology \& Society, vol. 14, no. 2, pp. 58-70. 
Financial Times 2012, .

Fishbein, M. \& Ajzen, I. 1975, Belief, attitude, intention and behavior: An introduction to theory and research, .

Gartner 2013, , Gartner Says Worldwide Mobile Phone Sales Declined 1.7 Percent in 2012. Available: http://www.gartner.com/newsroom/id/2335616.

Gartner 2011, , Gartner Says Worldwide Mobile Phone Sales Declined 1.7 Percent in 2012. Available: http://www.gartner.com/newsroom/id/1726614.

IBM 2012, .

Im, I., Hong, S. and Kang, M.S. 2011, "An international comparison of technology adoption: Testing the UTAUT model", Information \& Management, vol. 48, no. 1, pp. 1-8.

Iqbal, S. and Qureshi, I.A. 2012, "M-learning adoption: A perspective from a developing country", The International Review of Research in Open and Distance Learning, vol. 13, no. 3, pp. 147164.

ITU 2013, , ICT Facts and Figures. Available: http://www.itu.int/ITUD/ict/facts/material/ICTFactsFigures2013.pdf.

Jung, Y., Perez-Mira, B. and Wiley-Patton, S. 2009, "Consumer adoption of mobile TV: Examining psychological flow and media content", Computers in Human Behavior, vol. 25, no. 1, pp. 123 129.

Kalaiarasi, H. and Srividya, V. 2013, "A study on Wireless Banking Services-the case of mobile banking with integrated Technology Acceptance Model", Journal of Contemporary Research in Management, vol. 7, no. 3.

Karaiskos, D.C., Drossos, D.A., Tsiaousis, A.S., Giaglis, G.M. and Fouskas, K.G. 2012, "Affective and social determinants of mobile data services adoption", Behaviour \& Information Technology, vol. 31, no. 3, pp. 209-219.

Keegan, D. 2002, "The future of learning: From eLearning to mLearning", .

Kim, G., Shin, B. and Lee, H.G. 2009, "Understanding dynamics between initial trust and usage intentions of mobile banking", Information Systems Journal, vol. 19, no. 3, pp. 283-311.

Kim, H., Chan, H.C. and Gupta, S. 2007, "Value-based adoption of mobile internet: an empirical investigation", Decision Support Systems, vol. 43, no. 1, pp. 111-126.

Kuo, Y. and Yen, S. 2009, "Towards an understanding of the behavioral intention to use 3G mobile value-added services", Computers in Human Behavior, vol. 25, no. 1, pp. 103-110.

Lee, D., Chung, J.Y. and Kim, H. 2013, "Text me when it becomes dangerous: Exploring the determinants of college students' adoption of mobile-based text alerts short message service", Computers in Human Behavior, vol. 29, no. 3, pp. 563-569.

Lee, Y., Park, J., Chung, N. and Blakeney, A. 2012, "A unified perspective on the factors influencing usage intention toward mobile financial services", Journal of Business Research, vol. 65, no. 11, pp. 1590-1599. 
Liang, T. and Wei, C. 2004, "Introduction to the special issue: mobile commerce applications", International Journal of Electronic Commerce, vol. 8, no. 3, pp. 7-17.

Liao, C., Tsou, C. and Huang, M. 2007, "Factors influencing the usage of $3 \mathrm{G}$ mobile services in Taiwan", Online Information Review, vol. 31, no. 6, pp. 759-774.

Liaw, S., Hatala, M. and Huang, H. 2010, "Investigating acceptance toward mobile learning to assist individual knowledge management: Based on activity theory approach", Computers \& Education, vol. 54, no. 2, pp. 446-454.

Lin, H. 2011, "An empirical investigation of mobile banking adoption: the effect of innovation attributes and knowledge-based trust", International Journal of Information Management, vol. 31, no. 3, pp. 252-260.

Liu, Y. and Li, H. 2011, "Exploring the impact of use context on mobile hedonic services adoption: An empirical study on mobile gaming in China", Computers in Human Behavior, vol. 27, no. 2, pp. 890-898.

Liu, Y., Wang, S. and Wang, X. 2011, "A usability-centred perspective on intention to use mobile payment", International Journal of Mobile Communications, vol. 9, no. 6, pp. 541.

López-Nicolás, C., Molina-Castillo, F.J. and Bouwman, H. 2008, "An assessment of advanced mobile services acceptance: Contributions from TAM and diffusion theory models", Information \& Management, vol. 45, no. 6, pp. 359-364.

Lu, J., Yao, J.E. and Yu, C. 2005, "Personal innovativeness, social influences and adoption of wireless Internet services via mobile technology", The Journal of Strategic Information Systems, vol. 14 , no. 3, pp. 245-268.

Lu, J., Yu, C. and Liu, C. 2009, "Mobile data service demographics in urban China", Journal of Computer Information Systems, vol. 50, no. 2, pp. 117-126.

Mallat, N., Rossi, M., Tuunainen, V.K. and Öörni, A. 2009, "The impact of use context on mobile services acceptance: The case of mobile ticketing", Information \& Management, vol. 46, no. 3, pp. 190-195.

Moore, G.C. and Benbasat, I. 1991, "Development of an instrument to measure the perceptions of adopting an information technology innovation", Information systems research, vol. 2, no. 3, pp. 192-222.

Muk, A. 2007, "Cultural influences on adoption of SMS advertising: A study of American and Taiwanese consumers", Journal of Targeting, Measurement and Analysis for Marketing, vol. 16, no. 1, pp. 39-47.

Nysveen, H., Pedersen, P.E. and Thorbjørnsen, H. 2005, "Intentions to use mobile services: antecedents and cross-service comparisons", Journal of the Academy of Marketing Science, vol. 33, no. 3, pp. 330-346.

Okazaki, S. and Mendez, F. 2012, "Exploring convenience in mobile commerce: Moderating effects of gender", Computers in Human Behavior, . 
Park, S.Y. 2009, "An Analysis of the Technology Acceptance Model in Understanding University Students' Behavioral Intention to Use e-Learning.", Educational Technology \& Society, vol. 12, no. 3 , pp. $150-162$.

Park, Y. 2011, "A pedagogical framework for mobile learning: Categorizing educational applications of mobile technologies into four types", The International Review of Research in Open and Distance Learning, vol. 12, no. 2, pp. 78-102.

Pavlou, P.A. 2003, "Consumer acceptance of electronic commerce: integrating trust and risk with the technology acceptance model", International journal of electronic commerce, vol. 7, no. 3, pp. 101-134.

Persaud, A. and Azhar, I. 2012, "Innovative mobile marketing via smartphones: Are consumers ready?", Marketing Intelligence \& Planning, vol. 30, no. 4, pp. 418-443.

Qi, J., Li, L., Li, Y. and Shu, H. 2009, "An extension of technology acceptance model: analysis of the adoption of mobile data services in China", Systems Research and Behavioral Science, vol. 26, no. 3, pp. 391-407.

Roach, G. 2009, "Consumer perceptions of mobile phone marketing: a direct marketing innovation", Direct Marketing: An International Journal, vol. 3, no. 2, pp. 124-138.

Rogers, E. 1995, "M.(1995). Diffusion of innovations", The Free Press, New York, .

Rouibah, K., Abbas, H. and Rouibah, S. 2011, "Factors affecting camera mobile phone adoption before e-shopping in the Arab world", Technology in Society, vol. 33, no. 3, pp. 271-283.

Shih, Y. and Chen, C. 2013, "The study of behavioral intention for mobile commerce: via integrated model of TAM and TTF", Quality \& Quantity, vol. 47, no. 2, pp. 1009-1020.

Shin, D. 2011, "The influence of perceived characteristics of innovating on 4G mobile adoption", International Journal of Mobile Communications, vol. 9, no. 3, pp. 261-279.

Shin, D. 2012, "What makes consumers use VoIP over mobile phones? Free riding or consumerization of new service", Telecommunications Policy, vol. 36, no. 4, pp. 311-323.

Shin, D. 2009, "Towards an understanding of the consumer acceptance of mobile wallet", Computers in Human Behavior, vol. 25, no. 6, pp. 1343-1354.

Suki, N.M. 2011, "Factors affecting Third Generation (3G) mobile service acceptance: evidence from Malaysia", Journal of Internet Banking and Commerce, vol. 16, no. 1, pp. 1-12.

Tan, G.W., Ooi, K., Sim, J. and Phusavat, K. 2012, "DETERMINANTS OF MOBILE LEARNING ADOPTION: AN EMPIRICAL ANALYSIS", The Journal of Computer Information Systems, vol. 52, no. 3, pp. 82-91.

Tan, K.S., Chong, S.C., Loh, P.L. and Lin, B. 2010, "An evaluation of e-banking and m-banking adoption factors and preference in Malaysia: a case study", International Journal of Mobile Communications, vol. 8, no. 5, pp. 507-527.

Teng, W. and Lu, H. 2010, "Consumer adoption of PDA phones in Taiwan", International Journal of mobile communications, vol. 8, no. 1, pp. 1-20. 
Teo, A., Tan, G.W., Cheah, C., Ooi, K. and Yew, K. 2012, "Can the demographic and subjective norms influence the adoption of mobile banking?", International Journal of Mobile Communications, vol. 10, no. 6, pp. 578-597.

Thong, J.Y., Venkatesh, V., Xu, X., Hong, S. and Tam, K.Y. 2011, "Consumer acceptance of personal information and communication technology services", Engineering Management, IEEE Transactions on, vol. 58, no. 4, pp. 613-625.

Tsai, C. 2010, "An analysis of usage intentions for mobile travel guide systems", Afr.J.Bus.Manag, vol. 4, no. 13, pp. 2962-2970.

Van der Heijden, H. 2003, "Factors influencing the usage of websites: the case of a generic portal in The Netherlands", Information \& Management, vol. 40, no. 6, pp. 541-549.

Venkatesh, V. and Davis, F.D. 2000, "A theoretical extension of the technology acceptance model: four longitudinal field studies", Management science, vol. 46, no. 2, pp. 186-204.

Venkatesh, V., Morris, M.G., Davis, G.B. and Davis, F.D. 2003, "User acceptance of information technology: Toward a unified view", MIS quarterly, , pp. 425-478.

Venkatesh, V., Thong, J. and Xu, X. 2012, "Consumer acceptance and use of information technology: Extending the unified theory of acceptance and use of technology", MIS quarterly, vol. 36, no. 1, pp. 157-178.

Verkasalo, H., López-Nicolás, C., Molina-Castillo, F.J. and Bouwman, H. 2010, "Analysis of users and non-users of smartphone applications", Telematics and Informatics, vol. 27, no. 3, pp. 242255.

Wang, H. and Wang, S. 2010, "User acceptance of mobile internet based on the Unified Theory of Acceptance and Use of Technology: investigating the determinants and gender differences", Social Behavior and Personality: an international journal, vol. 38, no. 3, pp. 415-426.

Webster, J. and Watson, R.T. 2002, "ANALYZING THE PAST TO PREPARE FOR THE FUTURE: WRITING A", MIS quarterly, vol. 26, no. 2.

Wu, Y., Tao, Y. and YangJ, P. 2007, "Using UTAUT to explore the behavior of 3G mobile communication users", Industrial Engineering and Engineering Management, 2007 IEEE International Conference onIEEE, , pp. 199.

Yu, C. 2012a, "Factors Affecting Individuals to Adopt Mobile Banking: Empirical Evidence from the UTAUT Model", Journal of Electronic Commerce Research, vol. 13, no. 2, pp. 104-121.

Yu, C. 2012b, "Factors Affecting Individuals to Adopt Mobile Banking: Empirical Evidence from the UTAUT Model", Journal of Electronic Commerce Research, vol. 13, no. 2, pp. 104-121.

Zhang, J. 2009, "Exploring drivers in the adoption of mobile commerce in China", The Journal of American Academy of Business, vol. 15, no. 1, pp. 64-69.

Zhou, T. 2012, "Examining location-based services usage from the perspectives of unified theory of acceptance and use of technology and privacy risk", Journal of Electronic Commerce Research, vol. 13, no. 2, pp. 135-144. 
Zhou, T., Lu, Y. and Wang, B. 2010a, "Integrating TTF and UTAUT to explain mobile banking user adoption", Computers in Human Behavior, vol. 26, no. 4, pp. 760-767.

Zhou, T., Lu, Y. and Wang, B. 2010b, "Integrating TTF and UTAUT to explain mobile banking user adoption", Computers in Human Behavior, vol. 26, no. 4, pp. 760-767. 


\section{Appendix A}

\begin{tabular}{|c|c|c|c|c|c|c|c|c|c|}
\hline $\mathbf{N}$ & Author & Title & Journal & Year & $\begin{array}{l}\text { Technology } \\
\text { studied }\end{array}$ & $\begin{array}{c}\text { Sample } \\
\text { size }\end{array}$ & $\begin{array}{l}\text { Heterogene } \\
\text { ous sample? }\end{array}$ & $\begin{array}{l}\text { Survey } \\
\text { mode }\end{array}$ & $\begin{array}{c}\text { FW } \\
\text { location }\end{array}$ \\
\hline 1 & $\begin{array}{l}\text { Venkatesh et } \\
\text { al. }\end{array}$ & $\begin{array}{l}\text { Consumer acceptance and use of information } \\
\text { Technology: extending the unified theory of } \\
\text { acceptance and use of technology }\end{array}$ & MIS Quarterly & 2012 & $\begin{array}{l}\text { Mobile } \\
\text { Internet }\end{array}$ & $\begin{array}{l}4127 \\
1512\end{array}$ & Yes & Online & Hong Kong \\
\hline 2 & Kim et al. & $\begin{array}{l}\text { Value-based Adoption of Mobile Internet: An } \\
\text { empirical investigation }\end{array}$ & $\begin{array}{l}\text { Decision Support } \\
\text { Systems }\end{array}$ & 2007 & $\begin{array}{l}\text { Mobile } \\
\text { Internet }\end{array}$ & 161 & Yes & Online & Singapore \\
\hline 3 & D.-H. Shin & $\begin{array}{l}\text { Towards an understanding of the consumer } \\
\text { acceptance of mobile wallet }\end{array}$ & $\begin{array}{l}\text { Computers in Human } \\
\text { Behavior }\end{array}$ & 2009 & Mobile wallet & 296 & Yes & Online & US \\
\hline 4 & Park et al & $\begin{array}{l}\text { Adoption of Mobile Technologies for Chinese } \\
\text { Consumers }\end{array}$ & $\begin{array}{l}\text { Journal of Electronic } \\
\text { Commerce Research }\end{array}$ & 2007 & $\begin{array}{l}\text { Mobile } \\
\text { technologies }\end{array}$ & 221 & Yes & Online & China \\
\hline 5 & $\begin{array}{l}\text { L. S-L } \\
\text { Chen and } \\
\text { C.J. Kuan }\end{array}$ & $\begin{array}{l}\text { Customer acceptance of playing online game on } \\
\text { mobile phones }\end{array}$ & $\begin{array}{l}\text { International Journal of } \\
\text { Mobile } \\
\text { Communications }\end{array}$ & 2012 & $\begin{array}{l}\text { Mobile online } \\
\text { gaming }\end{array}$ & 610 & Yes & Online & Taiwan \\
\hline 6 & $\begin{array}{l}\text { T. Zhou et } \\
\text { al. }\end{array}$ & $\begin{array}{l}\text { Integrating TTF and UTAUT to explain mobile } \\
\text { banking user adoption }\end{array}$ & $\begin{array}{l}\text { Computers in Human } \\
\text { Behavior }\end{array}$ & 2010 & $\begin{array}{l}\text { Mobile } \\
\text { banking }\end{array}$ & 250 & Yes & Offline & China \\
\hline 7 & C.-S. Yu & $\begin{array}{l}\text { Factors Affecting Individuals to Adopt Mobile } \\
\text { Banking: Empirical Evidence from The UTAUT } \\
\text { Model }\end{array}$ & $\begin{array}{l}\text { Journal of Electronic } \\
\text { Commerce Research }\end{array}$ & 2012 & $\begin{array}{l}\text { Mobile } \\
\text { banking }\end{array}$ & 441 & Yes & Online & Taiwan \\
\hline 8 & Tao Zhou & $\begin{array}{l}\text { Examining LBS usage from the perspectives of } \\
\text { UTAUT and Privacy Risk }\end{array}$ & $\begin{array}{l}\text { Journal of Electronic } \\
\text { Commerce Research }\end{array}$ & 2012 & $\begin{array}{l}\text { Location based } \\
\text { services }\end{array}$ & 191 & Yes & Offline & China \\
\hline 9 & $\begin{array}{l}\text { Thong, } \\
\text { Venkatesh, } \\
\text { Xu, Hong, } \\
\text { Tam } \\
\end{array}$ & $\begin{array}{l}\text { Consumer Acceptance of Personal Information } \\
\text { and Communication Technology Services }\end{array}$ & $\begin{array}{l}\text { IEEE Transactions on } \\
\text { Engineering } \\
\text { Management }\end{array}$ & 2011 & \begin{tabular}{l|} 
Information \\
Communicatio \\
n services
\end{tabular} & 4777 & Yes & Online & Hong Kong \\
\hline 10 & $\begin{array}{l}\text { Gayar, } \\
\text { Moran, } \\
\text { Hawkes }\end{array}$ & $\begin{array}{l}\text { Students' Acceptance of Tablet PCs and } \\
\text { Implications for Educational Institutions }\end{array}$ & $\begin{array}{l}\text { Educational } \\
\text { Technology \& Society }\end{array}$ & 2011 & Tablet PC & 232 & Students & Online & US \\
\hline 11 & $\begin{array}{l}\text { Lu June, Yu } \\
\text { Chun- } \\
\text { Sheng, Liu } \\
\text { Change }\end{array}$ & $\begin{array}{l}\text { Mobile data service demographics in urban } \\
\text { China }\end{array}$ & $\begin{array}{l}\text { Journal of computer } \\
\text { information systems }\end{array}$ & 2009 & $\begin{array}{l}\text { Mobile data } \\
\text { services }\end{array}$ & 1320 & Yes & Offline & China \\
\hline 12 & $\begin{array}{l}\text { Y. Jung et } \\
\text { al. }\end{array}$ & $\begin{array}{l}\text { Consumer adoption of mobile TV: Examining } \\
\text { psychological flow and media content }\end{array}$ & $\begin{array}{l}\text { Computers in Human } \\
\text { Behavior }\end{array}$ & 2009 & Mobile TV & 208 & Yes & Online & Korea \\
\hline 13 & $\begin{array}{l}\text { J. Cheon et } \\
\text { al. }\end{array}$ & $\begin{array}{l}\text { An investigation of mobile learning readiness in } \\
\text { higher education based on the theory of planned } \\
\text { behavior }\end{array}$ & $\begin{array}{l}\text { Computers and } \\
\text { Education }\end{array}$ & 2012 & $\begin{array}{l}\text { Mobile } \\
\text { learning }\end{array}$ & 177 & Students & Offline & US \\
\hline 14 & $\begin{array}{l}\text { D. C. } \\
\text { Karaiskos } \\
\text { et al. }\end{array}$ & $\begin{array}{l}\text { Affective and social determinants of mobile data } \\
\text { service adoption }\end{array}$ & $\begin{array}{l}\text { Behaviour \& } \\
\text { Information } \\
\text { Technology }\end{array}$ & 2012 & $\begin{array}{l}\text { Mobile data } \\
\text { services }\end{array}$ & 219 & Yes & Online & Greece \\
\hline 15 & $\begin{array}{l}\text { Y. Liu, H. } \\
\mathrm{Li}\end{array}$ & $\begin{array}{l}\text { Exploring the impact of use context on mobile } \\
\text { hedonic services adoption: An empirical study } \\
\text { on mobile gaming in China }\end{array}$ & $\begin{array}{l}\text { Computers in Human } \\
\text { Behavior }\end{array}$ & 2011 & Mobile gaming & 267 & Students & Offline & China \\
\hline 16 & $\begin{array}{l}\text { K. Rouibah } \\
\text { et al. }\end{array}$ & $\begin{array}{l}\text { Factors affecting camera mobile phone adoption } \\
\text { before e-shopping in the Arab world }\end{array}$ & Technology in Society & 2011 & $\begin{array}{l}\text { Mobile camera } \\
\text { phone }\end{array}$ & 151 & Students & Offline & Kuwait \\
\hline 17 & $\begin{array}{l}\text { Y. Park, } \\
\text { J.V. Chen }\end{array}$ & $\begin{array}{l}\text { Acceptance and adoption of the innovative use } \\
\text { of smartphone }\end{array}$ & $\begin{array}{l}\text { Industrial Management } \\
\text { \& Data Systems }\end{array}$ & 2007 & Smartphone & 133 & $\begin{array}{l}\text { Doctors and } \\
\text { nurses }\end{array}$ & Offline & US \\
\hline 18 & $\begin{array}{l}\text { H. Dai, P.C. } \\
\text { Palvia }\end{array}$ & $\begin{array}{l}\text { Mobile Commerce Adoption in China and the } \\
\text { United States }\end{array}$ & $\begin{array}{l}\text { The DATA BASE for } \\
\text { Advances in } \\
\text { Information Systems }\end{array}$ & 2009 & $\begin{array}{l}\text { Mobile } \\
\text { commerce }\end{array}$ & 106 & $\begin{array}{l}\text { University } \\
\text { students }\end{array}$ & Offline & China \\
\hline 19 & $\begin{array}{l}\text { H. Dai, P.C. } \\
\text { Palvia }\end{array}$ & $\begin{array}{l}\text { Mobile Commerce Adoption in China and the } \\
\text { United States }\end{array}$ & $\begin{array}{l}\text { The DATA BASE for } \\
\text { Advances in } \\
\text { Information Systems }\end{array}$ & 2009 & $\begin{array}{l}\text { Mobile } \\
\text { commerce }\end{array}$ & 84 & $\begin{array}{l}\text { University } \\
\text { students }\end{array}$ & Offline & US \\
\hline 20 & $\begin{array}{l}\text { Iqbal and } \\
\text { Qureshi }\end{array}$ & $\begin{array}{l}\text { M-Learning Adoption: A Perspective from a } \\
\text { Developing Country }\end{array}$ & $\begin{array}{l}\text { The International } \\
\text { review of research in } \\
\text { open and distance } \\
\text { learning }\end{array}$ & 2012 & $\begin{array}{l}\text { Mobile } \\
\text { learning }\end{array}$ & 250 & $\begin{array}{l}\text { University } \\
\text { students }\end{array}$ & Offline & Pakistan \\
\hline 21 & $\begin{array}{l}\text { A. Persaud } \\
\text { and I. } \\
\text { Azhar }\end{array}$ & $\begin{array}{l}\text { Innovative mobile marketing via smartphones } \\
\text { Are consumers ready? }\end{array}$ & $\begin{array}{l}\text { Marketing Intelligence } \\
\text { \& Planning }\end{array}$ & 2012 & $\begin{array}{l}\text { Mobile } \\
\text { marketing }\end{array}$ & 428 & Yes & Online & Canada \\
\hline 22 & $\begin{array}{l}\text { R. Faullant, } \\
\text { J. Fuller, K. } \\
\text { Matzer }\end{array}$ & $\begin{array}{l}\text { Mobile Audience Interaction- Explaining the } \\
\text { adoption of new mobile service applications in } \\
\text { socially enriched environments }\end{array}$ & $\begin{array}{l}\text { Engineering } \\
\text { Management Research }\end{array}$ & 2012 & Mobile voting & 136 & Yes & Online & Germany \\
\hline 23 & $\begin{array}{l}\text { Y.K.Choi, } \\
\text { J.W.Totten }\end{array}$ & $\begin{array}{l}\text { Self-construal's role in mobile TV acceptance: } \\
\text { Extension of TAM across cultures }\end{array}$ & $\begin{array}{l}\text { Journal of Business } \\
\text { Research }\end{array}$ & 2012 & Mobile TV & 817 & $\begin{array}{l}\text { University } \\
\text { students }\end{array}$ & Offline & Korea \\
\hline 24 & $\begin{array}{l}\text { Y.K.Choi, } \\
\text { J.W.Totten }\end{array}$ & $\begin{array}{l}\text { Self-construal's role in mobile TV acceptance: } \\
\text { Extension of TAM across cultures }\end{array}$ & $\begin{array}{l}\text { Journal of Business } \\
\text { Research }\end{array}$ & 2012 & Mobile TV & 401 & $\begin{array}{l}\text { University } \\
\text { students }\end{array}$ & Offline & US \\
\hline 25 & $\begin{array}{l}\text { H.Y. Wang, } \\
\text { S.H. Wang }\end{array}$ & $\begin{array}{l}\text { User Acceptance of Mobile Internet Based on } \\
\text { UTAUT: Investigating the Determinants and } \\
\text { Gender Differences }\end{array}$ & $\begin{array}{l}\text { Social behavior and } \\
\text { personality }\end{array}$ & 2010 & $\begin{array}{l}\text { Mobile } \\
\text { Internet }\end{array}$ & 343 & Yes & Online & Taiwan \\
\hline 26 & $\begin{array}{l}\text { Y.Y. Shin, } \\
\text { C.Y. Chen }\end{array}$ & $\begin{array}{l}\text { The study of behavioral intention for mobile } \\
\text { commerce: via integrated model of TAM and } \\
\text { TTF }\end{array}$ & Qual Quant & 2011 & $\begin{array}{l}\text { Mobile } \\
\text { commerce }\end{array}$ & 421 & $\begin{array}{l}\text { Real Estate } \\
\text { agents }\end{array}$ & NA & Taiwan \\
\hline 27 & $\begin{array}{l}\text { S.Y. Park, } \\
\text { M.W. Nam, } \\
\text { S.B. Cha }\end{array}$ & $\begin{array}{l}\text { University students' behavioral intention to use } \\
\text { mobile learning: Evaluating the technology } \\
\text { acceptance model }\end{array}$ & $\begin{array}{l}\text { British Journal of } \\
\text { Educational } \\
\text { Technology }\end{array}$ & 2011 & $\begin{array}{l}\text { Mobile } \\
\text { learning }\end{array}$ & 288 & $\begin{array}{l}\text { University } \\
\text { students }\end{array}$ & Offline & Korea \\
\hline 28 & $\begin{array}{l}\text { B. Kim, I. } \\
\text { Han }\end{array}$ & $\begin{array}{l}\text { What drives the adoption of mobile data } \\
\text { services? An approach from a value perspective }\end{array}$ & $\begin{array}{l}\text { Journal of Information } \\
\text { Technology }\end{array}$ & 2009 & $\begin{array}{l}\text { Mobile data } \\
\text { services }\end{array}$ & 287 & $\begin{array}{l}\text { University } \\
\text { students }\end{array}$ & Offline & Korea \\
\hline 29 & D.-H. Shin & $\begin{array}{l}\text { What makes consumers use VoIP over mobile } \\
\text { phones? Free riding or consumerization of new } \\
\text { service }\end{array}$ & $\begin{array}{l}\text { Telecommunications } \\
\text { Policy }\end{array}$ & 2012 & Mobile voip & 329 & Yes & Online & Korea \\
\hline
\end{tabular}




\begin{tabular}{|c|c|c|c|c|c|c|c|c|c|}
\hline 30 & $\begin{array}{l}\text { G.W. Tan } \\
\text { et al. }\end{array}$ & $\begin{array}{l}\text { Determinants of mobile learning adoption: an } \\
\text { empirical analysis }\end{array}$ & $\begin{array}{l}\text { Journal of computer } \\
\text { information systems }\end{array}$ & 2012 & $\begin{array}{l}\text { Mobile } \\
\text { learning }\end{array}$ & 401 & $\begin{array}{l}\text { University } \\
\text { students }\end{array}$ & Offline & Malaysia \\
\hline 31 & D. Lee et al. & $\begin{array}{l}\text { Text me when it becomes dangerous: Exploring } \\
\text { the determinants of college students' adoption } \\
\text { of mobile-based text alerts short message } \\
\text { service }\end{array}$ & $\begin{array}{l}\text { Computers in Human } \\
\text { Behavior }\end{array}$ & 2013 & $\begin{array}{l}\text { Mobile text } \\
\text { message alert }\end{array}$ & 285 & $\begin{array}{l}\text { University } \\
\text { students }\end{array}$ & Online & US \\
\hline 32 & S. Lee & $\begin{array}{l}\text { An integrated adoption model for e-books in a } \\
\text { mobile environment: Evidence from South } \\
\text { Korea }\end{array}$ & $\begin{array}{l}\text { Telematics and } \\
\text { Informatics }\end{array}$ & 2013 & $\begin{array}{l}\text { Mobile e } \\
\text { books }\end{array}$ & 400 & Yes & Online & Korea \\
\hline 33 & $\begin{array}{l}\text { Chan- } \\
\text { Olmsted et } \\
\text { al. }\end{array}$ & $\begin{array}{l}\text { Mobile News Adoption among Young Adults: } \\
\text { Examining the Roles of Perceptions, News } \\
\text { Consumption, and Media Usage }\end{array}$ & $\begin{array}{l}\text { Journalism \& Mass } \\
\text { Communication } \\
\text { Quarterly }\end{array}$ & 2012 & Mobile news & 384 & $\begin{array}{l}\text { University } \\
\text { students }\end{array}$ & Online & US \\
\hline 34 & $\begin{array}{l}\text { T. Zarmpou } \\
\text { et al. }\end{array}$ & Modeling users' acceptance of mobile services & $\begin{array}{l}\text { Electronic Commerce } \\
\text { Research }\end{array}$ & 2012 & $\begin{array}{l}\text { Mobile } \\
\text { services }\end{array}$ & 445 & Yes & Both & Greece \\
\hline 35 & $\begin{array}{l}\text { U. Akturan, } \\
\text { N. Tezcan }\end{array}$ & $\begin{array}{l}\text { Mobile banking adoption of the youth market } \\
\text { Perceptions and intentions }\end{array}$ & $\begin{array}{l}\text { Marketing Intelligence } \\
\text { \& Planning }\end{array}$ & 2012 & $\begin{array}{l}\text { Mobile } \\
\text { banking }\end{array}$ & 435 & $\begin{array}{l}\text { University } \\
\text { students }\end{array}$ & Offline & Turkey \\
\hline 36 & $\begin{array}{l}\text { R. Peng, L. } \\
\text { Xiong, Z. } \\
\text { Yang }\end{array}$ & $\begin{array}{l}\text { Exploring Tourist Adoption of Tourism Mobile } \\
\text { Payment: An Empirical Analysis }\end{array}$ & $\begin{array}{l}\text { Journal of Theoretical } \\
\text { and Applied Electronic } \\
\text { Commerce Research }\end{array}$ & 2012 & $\begin{array}{l}\text { Mobile } \\
\text { payment } \\
\text { (tourism) }\end{array}$ & 421 & $\begin{array}{l}\text { Tourist in } \\
\text { China }\end{array}$ & Offline & China \\
\hline 37 & N.M. Suki & $\begin{array}{l}\text { Factors Affecting Third Generation Mobile } \\
\text { Service Acceptance: Evidence from Malaysia }\end{array}$ & $\begin{array}{l}\text { Journal of Internet } \\
\text { Banking and } \\
\text { Commerce }\end{array}$ & 2011 & 3G services & 100 & NA & NA & Malaysia \\
\hline 38 & $\begin{array}{l}\text { Z. Li, X. } \\
\text { Bai }\end{array}$ & $\begin{array}{l}\text { An Empirical Study of the Influencing Factors } \\
\text { of User Adoption on Mobile Securities Services }\end{array}$ & Journal of Software & 2011 & $\begin{array}{l}\text { Mobile } \\
\text { securities }\end{array}$ & 174 & Yes & Offline & China \\
\hline 39 & Z. Liu et al. & $\begin{array}{l}\text { A Study of Mobile Instant Messaging adoption: } \\
\text { within-culture variation }\end{array}$ & $\begin{array}{l}\text { International Journal of } \\
\text { Mobile } \\
\text { Communications }\end{array}$ & 2011 & $\begin{array}{l}\text { Mobile instant } \\
\text { messaging }\end{array}$ & 837 & Yes & Online & China \\
\hline 40 & $\begin{array}{l}\text { N. Mallat et } \\
\text { al. }\end{array}$ & $\begin{array}{l}\text { The impact of use context on mobile services } \\
\text { acceptance: The case of mobile ticketing }\end{array}$ & $\begin{array}{l}\text { Information and } \\
\text { Management }\end{array}$ & 2009 & $\begin{array}{l}\text { Mobile } \\
\text { ticketing }\end{array}$ & 360 & Yes & Offline & Finland \\
\hline 41 & J. Zhang & $\begin{array}{l}\text { Exploring drivers in the adoption of mobile } \\
\text { commerce in China }\end{array}$ & $\begin{array}{l}\text { Journal of American } \\
\text { Academy of Business }\end{array}$ & 2009 & $\begin{array}{l}\text { Mobile } \\
\text { commerce }\end{array}$ & 2160 & Yes & Offline & China \\
\hline 42 & $\begin{array}{l}\text { C-T.B. Ho } \\
\text { et al. }\end{array}$ & $\begin{array}{l}\text { Technology adoption of mobile learning: a } \\
\text { study of podcasting }\end{array}$ & $\begin{array}{l}\text { International Journal of } \\
\text { Mobile } \\
\text { Communications }\end{array}$ & 2010 & $\begin{array}{l}\text { Mobile } \\
\text { learning: } \\
\text { podcasting }\end{array}$ & 246 & Yes & Online & Taiwan \\
\hline 43 & $\begin{array}{l}\text { W. Teng, } \\
\text { H-P. Lu }\end{array}$ & Consumer adoption of PDA phones in Taiwan & $\begin{array}{l}\text { International Journal of } \\
\text { Mobile } \\
\text { Communications }\end{array}$ & 2010 & $\begin{array}{l}\text { Smartphone } \\
\text { (PDA) }\end{array}$ & 326 & $\begin{array}{l}\text { University } \\
\text { students }\end{array}$ & Offline & Taiwan \\
\hline 44 & $\begin{array}{l}\text { L. Qi, L. Li, } \\
\text { Y. Li, H. } \\
\text { Shu }\end{array}$ & $\begin{array}{l}\text { An Extension of Technology Acceptance } \\
\text { Model: Analysis of the Adoption of Mobile } \\
\text { Data Services in China }\end{array}$ & $\begin{array}{l}\text { Systems Research and } \\
\text { Behavioral Science }\end{array}$ & 2009 & $\begin{array}{l}\text { Mobile data } \\
\text { services }\end{array}$ & 802 & Yes & Offline & China \\
\hline 45 & $\begin{array}{l}\text { Oye, Lahad, } \\
\text { Rahim }\end{array}$ & $\begin{array}{l}\text { Acceptance and Usage of ICT by University } \\
\text { Academicians Using UTAUT Model: A Case } \\
\text { Study of University of Port Harcourt, Nigeria }\end{array}$ & $\begin{array}{l}\text { Journal of Emerging } \\
\text { Trends in Computing } \\
\text { and Information } \\
\text { Sciences }\end{array}$ & 2012 & $\begin{array}{l}\text { Information } \\
\text { Communicatio } \\
\mathrm{n} \text { services }\end{array}$ & 100 & $\begin{array}{l}\text { Department } \\
\text { staff }\end{array}$ & Offline & Nigeria \\
\hline 46 & Chen et al. & $\begin{array}{l}\text { Applicability of the UTAUT Model in Playing } \\
\text { Online Game through Mobile Phones: } \\
\text { Moderating Effects of User Experience }\end{array}$ & $\begin{array}{l}\text { IEEE Int'l Technology } \\
\text { Management } \\
\text { Conference }\end{array}$ & 2011 & $\begin{array}{l}\text { Mobile online } \\
\text { gaming }\end{array}$ & 610 & Yes & Online & Taiwan \\
\hline 47 & $\begin{array}{l}\text { Y.-K Lee et } \\
\text { al. }\end{array}$ & $\begin{array}{l}\text { A unified perspective on the factors influencing } \\
\text { usage intention toward mobile financial services }\end{array}$ & $\begin{array}{l}\text { Journal of Business } \\
\text { Research }\end{array}$ & 2012 & $\begin{array}{l}\text { Mobile } \\
\text { financial } \\
\text { services }\end{array}$ & 240 & Yes & Online & Korea \\
\hline 48 & $\begin{array}{l}\text { H. } \\
\text { Kalaiarasi, } \\
\text { Dr. V. } \\
\text { Srividya } \\
\end{array}$ & $\begin{array}{l}\text { A study on Wireless Banking Services - the case } \\
\text { of mobile banking with integrated Technology } \\
\text { Acceptance Model }\end{array}$ & $\begin{array}{l}\text { Journal of } \\
\text { Contemporary } \\
\text { Research in } \\
\text { Management }\end{array}$ & 2012 & $\begin{array}{l}\text { Mobile } \\
\text { banking }\end{array}$ & 209 & Yes & Offline & India \\
\hline 49 & Liu et al. & $\begin{array}{l}\text { A usability-centred perspective on intention to } \\
\text { use mobile payment }\end{array}$ & $\begin{array}{l}\text { International Journal of } \\
\text { Mobile } \\
\text { Communications }\end{array}$ & 2011 & $\begin{array}{l}\text { Mobile } \\
\text { payment }\end{array}$ & 202 & $\begin{array}{l}\text { University } \\
\text { students }\end{array}$ & Both & China \\
\hline 50 & $\begin{array}{l}\text { G. Jiang } \\
\text { and W. } \\
\text { Deng }\end{array}$ & $\begin{array}{l}\text { An empirical analysis of factors influencing the } \\
\text { adoption of Mobile Instant Messaging in China }\end{array}$ & $\begin{array}{l}\text { International Journal of } \\
\text { Mobile } \\
\text { Communications }\end{array}$ & 2011 & $\begin{array}{l}\text { Mobile instant } \\
\text { messaging }\end{array}$ & 364 & Yes & Both & China \\
\hline 51 & $\begin{array}{l}\text { H. Amin, } \\
\text { M.R.A. } \\
\text { Hamid, S. } \\
\text { Lada, Z. } \\
\text { Anis }\end{array}$ & $\begin{array}{l}\text { The Adoption of mobile banking in Malaysia: } \\
\text { the case of Bank Islam Malaysia Berhad } \\
\text { (BIMB) }\end{array}$ & $\begin{array}{l}\text { International Journal of } \\
\text { Business and Society }\end{array}$ & 2008 & $\begin{array}{l}\text { Mobile } \\
\text { banking }\end{array}$ & 158 & Yes & Offline & Malaysia \\
\hline 52 & Y. Liu et al. & $\begin{array}{l}\text { Factors driving the adoption of m-learning: An } \\
\text { empirical study }\end{array}$ & $\begin{array}{l}\text { Computers and } \\
\text { Education }\end{array}$ & 2010 & $\begin{array}{l}\text { Mobile } \\
\text { learning }\end{array}$ & 209 & $\begin{array}{l}\text { University } \\
\text { students }\end{array}$ & Offline & China \\
\hline 53 & $\begin{array}{l}\text { C. Lopez- } \\
\text { Nicolas et } \\
\text { al. }\end{array}$ & $\begin{array}{l}\text { An assessment of advanced mobile services } \\
\text { acceptance: Contributions from TAM and } \\
\text { diffusion theory models }\end{array}$ & $\begin{array}{l}\text { Information and } \\
\text { Management }\end{array}$ & 2008 & $\begin{array}{l}\text { Mobile } \\
\text { services } \\
\text { (advanced) }\end{array}$ & 542 & Yes & Online & Netherlands \\
\hline 54 & $\begin{array}{l}\text { T.R. Lee et } \\
\text { al. }\end{array}$ & $\begin{array}{l}\text { Adoption of mobile Location-Based Services } \\
\text { with Zaltman Metaphor Elicitation Techniques }\end{array}$ & $\begin{array}{l}\text { International Journal of } \\
\text { Mobile } \\
\text { Communications }\end{array}$ & 2009 & $\begin{array}{l}\begin{array}{l}\text { Location based } \\
\text { services }\end{array} \\
\end{array}$ & 196 & Yes & NA & Taiwan \\
\hline 55 & C.-Y. Tsai & $\begin{array}{l}\text { An analysis of usage intentions for mobile travel } \\
\text { guide systems }\end{array}$ & $\begin{array}{l}\text { African Journal of } \\
\text { Business Management }\end{array}$ & 2010 & $\begin{array}{l}\text { Mobile travel } \\
\text { guide systems }\end{array}$ & 175 & Yes & Offline & Taiwan \\
\hline 56 & S. Lee et al. & $\begin{array}{l}\text { An integrated adoption model for mobile } \\
\text { services }\end{array}$ & $\begin{array}{l}\text { International Journal of } \\
\text { Mobile } \\
\text { Communications }\end{array}$ & 2012 & $\begin{array}{l}\text { Mobile } \\
\text { services }\end{array}$ & 777 & Yes & Online & Korea \\
\hline 57 & $\begin{array}{l}\text { J-L. Chong } \\
\text { et al. }\end{array}$ & $\begin{array}{l}\text { An empirical analysis of the adoption of m- } \\
\text { learning in Malaysia }\end{array}$ & $\begin{array}{l}\text { International Journal of } \\
\text { Mobile } \\
\text { Communications }\end{array}$ & 2011 & $\begin{array}{l}\text { Mobile } \\
\text { learning }\end{array}$ & 181 & $\begin{array}{l}\text { Students, } \\
\text { lecturers }\end{array}$ & Offline & Malaysia \\
\hline 58 & $\begin{array}{l}\text { A-C. Teo et } \\
\text { al. }\end{array}$ & $\begin{array}{l}\text { Can the demographic and subjective norms } \\
\text { influence the adoption of mobile banking? }\end{array}$ & $\begin{array}{l}\text { International Journal of } \\
\text { Mobile } \\
\text { Communications }\end{array}$ & 2012 & $\begin{array}{l}\text { Mobile } \\
\text { banking }\end{array}$ & 193 & NA & Both & Malaysia \\
\hline 59 & D-H. Shin & $\begin{array}{l}\text { The influence of perceived characteristics of } \\
\text { innovating on } 4 \mathrm{G} \text { mobile adoption }\end{array}$ & $\begin{array}{l}\text { International Journal of } \\
\text { Mobile } \\
\text { Communications }\end{array}$ & 2011 & $4 \mathrm{G}$ & NA & NA & NA & Korea \\
\hline 60 & J. Lu et al. & $\begin{array}{l}\text { Personal innovativeness, social influences and } \\
\text { adoption of wireless Internet services via mobile } \\
\text { technology }\end{array}$ & $\begin{array}{l}\text { Journal of Strategic } \\
\text { Information Systems }\end{array}$ & 2005 & $\begin{array}{l}\text { Wireless } \\
\text { Internet } \\
\text { Services }\end{array}$ & 357 & $\begin{array}{l}\text { University } \\
\text { students }\end{array}$ & Both & US \\
\hline
\end{tabular}




\begin{tabular}{|c|c|c|c|c|c|c|c|c|c|}
\hline 61 & T. Bhatti & $\begin{array}{l}\text { Exploring Factors Influencing the Adoption of } \\
\text { Mobile Commerce }\end{array}$ & $\begin{array}{l}\text { Journal of Internet } \\
\text { Banking and } \\
\text { Commerce }\end{array}$ & 2007 & $\begin{array}{l}\text { Mobile } \\
\text { commerce }\end{array}$ & NA & $\begin{array}{l}\text { Yes (uni } \\
\text { people) }\end{array}$ & NA & UAE \\
\hline 62 & $\begin{array}{l}\text { Mahatanan } \\
\text { koon, Wen, } \\
\text { Lim }\end{array}$ & $\begin{array}{l}\text { Evaluating the technological characteristics and } \\
\text { trust affecting mobile device usage }\end{array}$ & $\begin{array}{l}\text { International Journal of } \\
\text { Mobile } \\
\text { Communications }\end{array}$ & 2006 & Mobile device & 212 & $\begin{array}{l}\text { University } \\
\text { students }\end{array}$ & Online & US \\
\hline 63 & $\begin{array}{l}\text { L-Y. Leong } \\
\text { et al. }\end{array}$ & $\begin{array}{l}\text { Influence of individual characteristics, perceived } \\
\text { usefulness and ease of use on mobile } \\
\text { entertainment adoption }\end{array}$ & $\begin{array}{l}\text { International Journal of } \\
\text { Mobile } \\
\text { Communications }\end{array}$ & 2011 & $\begin{array}{l}\text { Mobile } \\
\text { entertainment }\end{array}$ & 423 & $\begin{array}{l}\text { University } \\
\text { students }\end{array}$ & Offline & Malaysia \\
\hline 64 & $\begin{array}{l}\text { C-L. Hsu et } \\
\text { al. }\end{array}$ & $\begin{array}{l}\text { Investigating customer adoption behaviours in } \\
\text { Mobile Financial Services }\end{array}$ & $\begin{array}{l}\text { International Journal of } \\
\text { Mobile } \\
\text { Communications }\end{array}$ & 2011 & $\begin{array}{l}\text { Mobile } \\
\text { financial } \\
\text { services }\end{array}$ & 275 & Yes & Online & Taiwan \\
\hline 65 & $\begin{array}{l}\text { Y.-F. Kuo, } \\
\text { S.-N. Yen }\end{array}$ & $\begin{array}{l}\text { Towards an understanding of the behavioral } \\
\text { intention to use } 3 \mathrm{G} \text { mobile value-added services }\end{array}$ & $\begin{array}{l}\text { Computers in Human } \\
\text { Behavior }\end{array}$ & 2009 & 3G services & 269 & Students & Offline & Taiwan \\
\hline 66 & $\begin{array}{l}\text { A.Y-L. } \\
\text { Chong et al. }\end{array}$ & $\begin{array}{l}\text { Adoption of 3G services among Malaysian } \\
\text { consumers: an empirical analysis }\end{array}$ & $\begin{array}{l}\text { International Journal of } \\
\text { Mobile } \\
\text { Communications }\end{array}$ & 2010 & 3G services & 278 & Yes & Offline & Malaysia \\
\hline 67 & $\begin{array}{l}\text { K.S. Tan et } \\
\text { al. }\end{array}$ & $\begin{array}{l}\text { An evaluation of e-banking and m-banking } \\
\text { adoption factors and preference in Malaysia: a } \\
\text { case study }\end{array}$ & $\begin{array}{l}\text { International Journal of } \\
\text { Mobile } \\
\text { Communications }\end{array}$ & 2010 & $\begin{array}{l}\text { Mobile } \\
\text { banking }\end{array}$ & 184 & $\begin{array}{l}\text { University } \\
\text { students }\end{array}$ & Offline & Malaysia \\
\hline
\end{tabular}


Appendix B

\begin{tabular}{|l|l|}
\hline N & Journal \\
\hline 1 & MIS Quarterly \\
\hline 2 & Marketing Intelligence \& Planning \\
\hline 3 & Information and Management \\
\hline 4 & International Journal of Business and Society \\
\hline 5 & International Journal of Mobile Communications \\
\hline 6 & Behavior \& Information Technology \\
\hline 7 & Computers \& Education \\
\hline 8 & Computers in Human Behavior \\
\hline 9 & Decision Support Systems \\
\hline 10 & Engineering Management Research \\
\hline 11 & IEEE Int'1 Technology Management Conference \\
\hline 12 & IEEE Transactions on Engineering Management \\
\hline 13 & Journal of American Academy of Business \\
\hline 14 & Journal of Business Research \\
\hline 15 & Journal of computer information systems \\
\hline 16 & Journal of Contemporary Research in Management \\
\hline 17 & Journal of Electronic Commerce Research \\
\hline 18 & Journal of Internet Banking and Commerce \\
\hline 19 & Journal of Software \\
\hline 20 & Social behavior and personality \\
\hline 21 & Systems Research and Behavioral Science \\
\hline 22 & Telecommunications Policy \\
\hline 23 & Telematics and Informatics \\
\hline 24 & African Journal of Business Management \\
\hline
\end{tabular}




\section{Appendix C}

\begin{tabular}{|l|l|}
\hline Acronyms & Definition \\
\hline UTAUT & $\begin{array}{l}\text { Unified Theory of Acceptance and Use of } \\
\text { Technology }\end{array}$ \\
\hline TAM & Technology Acceptance Model \\
\hline TRA & Theory of Reasoned Action \\
\hline FVM & Fit-viability Model \\
\hline TPB & Theory of Planned Behavior \\
\hline DOI & Diffusion of Innovation \\
\hline IBM & International Business Machines \\
\hline IDT & Innovation Diffusion Theory \\
\hline TTF & Task Technology Fit \\
\hline PEOU & Perceived ease of use \\
\hline BI & Behavioral intention \\
\hline PE & Performance expectancy \\
\hline EE & Effort expectancy \\
\hline SI & Social influence \\
\hline FC & Facilitating conditions \\
\hline SN & Social norms \\
\hline PU & Perceived usefulness \\
\hline
\end{tabular}

